\title{
東北農業経済学会会長淽谷長生 挨拶
}

\section{1.はじめに}

当学会の学会長を務めております, 弘前大学の 㗪谷長生と申します。本学会の大会を開催するに あたり一言ご挨拶申し上げます。

まず本学会の開催にあたり，実行委員会を結成 して頂き大会を準備して頂いた岩手大学の横山実 行委員長, 並び佐藤事務局長そして関倸者の多く の方々にお礼を申し上げます。

また本大会の共催となって頂いた岩手大学三陸 復興機構, 岩手県, 農研機構・東北農業研究セン ター, JA 岩手県中央会, 岩手県農業会議, 岩手県 土地改良事業団体連合会，公益社団法人岩手県農 業公社の各組織に対し感謝申し上げます。

本学会は 2011 年 3 月 11 日の東日本大震災そし て福島原発事故の発生を受けまして, 12 年から 14 年までの 3 力年にわたり大震災と原発事故に関連 する企画を本大会シンポジュウム，並びに大会と は別にプレシンポジュウムを開催し，被災の寒態 並びに復興について幅広く情報交換と意見交換す ることを決めてきました。

これまで宮城大会, 福島大会で議論してきた内 容を踏まえ今年度は最終年度としてその中間的ま とめを行うこととしています。

また明日の個別報告では 33 の報告が予定され ており，近年にない多くの方の報告申し込みがあ りました。

さらに明日午後にはミニシンポジュウムとして 「新政策に対する担い手の動向と展開方向-岩手 県の実態を踏まえてー」を企画しました。これは岩 手県の各研究者並びに農業者を交えての報告と · 討論となります．是非これらの討論に参加して頂 きたいと考えております。

\section{2. 農政改革の嵐}

ところで政府の規制改革会議は6月13日規制改 革に関する第 2 次答申をまとめ安倍首相に提出し ました。農業分野では農協，農業生産法人，農業
委員会の見直しを断行してゆくと明記しました。

その中で農業委員会と農業生産法人，農協の見 直しは，自民党が 6 月 10 日にまとめた改革案を踏 まえた内容に修正され，都道府県農業会議や全国 農業会議所，農協の中央会制度は 5 月に提起され た「廃止」ではなく，「新たな制度への移行」と 変更されたのでした。

\section{3. 農業委員会の改革}

農業委員会の改革では，選挙制度と議会・団体 推薦による委員の選任制度を廃止し，市町村長の 選任制に一元化する。ただ，選任は市町村議会の 同意を要件とし，「事前に地域からの推薦・公募 などを行える」としました。

経済界の関心が高かった農業生産法人の出資要 件については規制改革会議の当初の考え通りには ならず出資要件の緩和は $50 \%$ 未満で当面は落ち 着くことになりました．他方で農業委員の選出に ついて議会の同意という新たな要件を条件とした が，選任制はそのまま答申された。

\section{4. 農業委員会制度はどうあるべきか}

農業委員会制度が硬直しているとの批判はこれ までもありました。農業委員は公選制と言いなが ら，多くの地域では無投票で選出され，名誉職的 な位置となっていることなどありました．それも あって農地流動化や耕作放棄地の解消に向けての 農業委員の活動が十分行われていないのではない か. また規模拡大希望農家など意欲的な農家が農 業委員となっていないため農業のあり方を踏まえ た判断がなされていないなどが代表的な意見で す。そうした問題点を踏まえるならば改革の必要 性もわからないわけではない. しかし現場での改 革の内容と今回の規制改革会議が答申した改革案 には大きな開きがあると思われます。

\section{5. 抜本的な農協改革を目指すとした規制改革会}


議

また規制改革会議の農協に関わる部分は以下の ようなものです。

○個々の農協の指導や政治への働きかけで中核と なっている全中は, 農協法の根拠規定をなくし, 必要なら任意の団体として活動してもらう。

○個々の農協は, 組合員のために肥料や農薬, 機 械などを購入し，農産品を販売する「経済事業」

に集中する.

○貯金や住宅ローンといった「信用（金融）事業」 はグループ内の農林中央金庫に任せるか，農林中 金からの空口業務の受託にとどめる一。

\section{6. 農協はさらなる飛躍を目指してほしい}

当然のことながら J A 側は「グループの解体に つながる．民間組織の J Aに政府が口出しするの はおかしい」と激しく反発しています。これまで の自民党と農協の関係を考えるならばこのような 乱暴な議論が出ることは想定できなかったのでし 上う，全国の農協組織は地元選出の自民党国会議 員に規制改革会議の案は受け入れられないので協 力（反対）してほしい旨の申し入れを行っていま す、「これまで一生䀣命自民党を応援してきたの に，恩を仇で返すのか」との憤りが農協界には渦 巻いています. 対応した自民党国会議員からは「我 々が規制改革会議の案は認めないから安心しろ」 との反応がほとんどのようでした.

しかし肝心の安倍首相は「農協のあり方につい て抜本的に見直す」（5月20日付朝日）と農協改 革に意欲満々です。

農協と自民党は規制改革会議による農協改革案 を「拒否する」のか, あるいはこれまでたびたび やってきたように「抜け道」を探すのか，それと も安倍政権に右ならえするのか，未だ帚趨は見通 せませんが，この議論が農業・農村にとって農協 はどんな役割を今後も果たしてゆくのかの議論に 結びつくことを期待したいと思います。 また農協 界からは「今次の農協改革論は農協に対する言い がかり的暴論である」と力強く言えるような体質 強化と魅力ある農協づくりを目指してほしいと考 えている。

\section{7. 最後に}

いずれにしろ戦後の農業のあり方を根本的に議 論しなければならない時代を迎えていることをひ しひしと感じ，その意味では当学会の果たすべき 役割もますます重要になっています.

本学会は今年で 50 周年を迎えることになりま した.その記念事業として今年 11 月に若手会員を 中心に 4 つセッションで今後の東北農業の研究 視点を提示してもらう企画を検討しています。そ うした事業を通じて本学会の役割をさらに充実さ せたいと思っています。

最後に学会のシンポジュウム報告準備のために 報告者の皆様には大変なご苦労をかけたと思いま す. 改めてお礼申し上げます，そして本日参加し て頂いた方々には最後までシンポジュウムの報告 と討論に参加して頂くことをお願いしまして挨拶 に代えさせて頂きます。 